\title{
Analysis of Parang Mask Batik Character Education as a Form of Character Building for Elementary School Children
}

\author{
Belinda Dewi Regina ${ }^{1 *}$, Arinta Rezty Wijayaningputri ${ }^{1}$ \\ ${ }^{1}$ Department of Elementary Teacher Education, Faculty of Teacher Training and Education, \\ Muhammadiyah University of Malang, Indonesia \\ belindadewi@umm.ac.id
}

Abstract

Batik is one of the crafts in Indonesia. The form and function of batik has developed. Formerly used by the royal court, now it is not. Every batik work produced has a character in it. These characters are found in their cultural background, beliefs, customs, and tastes. This makes batik a vehicle for cultivating character values. It is feared that the potential for Indonesian batik will be eroded without the preservation of Indonesian society. Although Indonesia has produced a lot of batik, there are still a few that show its distinctive features. Recently, batik appears in Malang, but it does not have a patent right. So it does not yet have a unique batik motif. Even though it does not have a patent right, there is batik that is well known in Malang, namely the Parang Mask batik from the Panji figure. In the batik motif is associated with the values of character education including religious, nationalist, independent, mutual cooperation and integrity as a form of character building for elementary school children. Therefore, the purpose of this study is to describe the character education of Parang Mask batik as a form of character building for elementary school children. This study uses a qualitative approach with this type of descriptive research. The subject is Parang Mask batik. The character values in the Parang Mask batik are religious values, nationalist values and also the value of mutual cooperation.

Keywords: character education; elementary education; Parang mask batik.

\section{INTRODUCTION}

The ancestors of the Indonesian people have given a legacy of highly valued and well-known artistic creations, including batik. Batik is one of Indonesia's cultural arts which has been integrated with Indonesian people since several centuries ago (Hapsari, 2015: 99). Batik has become one of the most popular types of craft art known as
Indonesian tradition. However, due to the rapid development of the era, batik is now experiencing a wider development, both in form and function. This happens because of an effort made by humans to create new forms in the process of development.

Batik in Indonesia has developed a lot along with the development of culture. But the development that continues to 
emerge does not eliminate the characteristics of batik itself which has traditional values and has a deep meaning and philosophy (Koniyo, Lamusu, Hadjaratie, \& Bouty, 2015). Many things are revealed from the art of batik, such as cultural background, beliefs, customs, nature, life order, natural environment, taste and skill level. With batik too, humans indirectly will learn to be patient, creative and innovative. Meaning in works like this is what makes batik a vehicle for instilling noble character values and expressions of love. Character education is a conscious and planned human effort to educate and empower students' potentials to build their personal character so that they can become individuals who benefit themselves and their environment (Nihayah, 2017: 1653).

At present, batik is not only used by the royal court for activities or events that are official, but almost all people from all walks of life have and have used batik in various daily events. Advances in increasingly sophisticated technology have supported the development of batik in Indonesian. This can be seen from the batik that was traditionally made using canting, but now there are many batik productions using a printing machine, using print in a short time and in large quantities.

Batik is not only known in the country, but also the main attraction of foreign communities. The potential of Indonesian batik is feared to be eroded without any preservation and development efforts made by Indonesian batik artisans. The existence of Indonesian batik is greatly supported by the development of batik itself both in terms of unique motifs, colouring, symbolic meaning contained and the price of batik on the market. Therefore, as the next generation of this valuable culture it is appropriate to maintain, preserve, and make batik as part of the Nation's Character. Indonesia is obliged to promote batik throughout the world so that it is better known and loved.

In East Java Province, there are several batik-producing cities that are already well-known by the wider community, both by the people of East Java themselves and communities outside the province, such as Madura batik, Jombang batik, Tuban batik, Madiun batik, Ponorogo batik, and other batik in East Java. The rapid development of batik has made batik craftsmen think to create new motifs that are very interesting and have high selling points. But recently there was a batikproducing city that began to emerge in East Java, one of which originated from Malang with the typical Malangan batik, the Parang Mask batik. This masked machete batik imitates the character of Panji Asmarabangun which is quite famous in the city of Malang. Malangan Batik began to be made in 2008.

As the development of batik in Malang, there is very little knowledge about batik, especially for elementary school students. Therefore, gradually batik is included in the learning of cultural arts based on character 
education. Because in Malang the banner mask is quite famous, so we introduce the character values contained in the mask. Not a few elementary schools have been taught to make batik, including batik, Shibori batik and also batik stamp from natural materials. Batik is included in the SBDP subject for elas 1 to grade 6 .

Based on the uniqueness found in the Parang Mask batik character, the writer is interested in conducting a study entitled "Character Education of Parang Mask Batik as a Form of Character Building for Elementary School Children ".

\section{LITERATURE REVIEW \\ a. Strengthening Character Education}

The Strengthening Movement for Character Education in addition to being a continuation and continuation of the National Movement for Nation Character Education in 2010 is also an integral part of Nawacita and to implement President Joko Widodo-Jusuf Kalla's Nawacita in the national education system (Effendy, 2016). This PPK policy is integrated in the National Movement for Mental Revolution (GNRM), which is a change in the way of thinking, behaving, and acting for the better. The main values of strengthening character education are religious, nationalist, independent, mutual cooperation, integrity. These values want to be instilled and practiced through the national education system so that they are known, understood, and applied in all aspects of life in schools and in society.
Strengthening Character Education was born because of the awareness of future challenges that are increasingly complex and uncertain, but at the same time see that there is a lot of hope for the future of the nation. This requires educational institutions to prepare students in terms of science and personality, in the form of individuals who are strong in moral, spiritual and scientific values. Understanding the background, urgency, and basic concepts of Strengthening Character Education is very important for principals to be able to apply it in accordance with the context of education in their respective regions. Implementation is a program of Strengthening Character Education through a habituation activity in order to improve the quality of a school and begins by planning an activity through Internal Quality Assurance System (SPMI) and drafting Competency Standards for Graduation (SKL) which will later have an impact on changes in the lesson plans, curriculum, schedule of lessons, and the implementation of SOPs. The function of the value of Character Education is as follows:

1. To develop basic potential in human beings so that they become goodminded, good-hearted, and wellbehaved individuals.

2. To build and strengthen multicultural community behaviour.

3. To build and enhance a competitive national civilization in international relations.

The characters are as follows: 1). Building and equipping students as the 
golden generation of Indonesia in 2045 to face the dynamics of change in the future. 2) Develop a national education platform that places character education as the main soul by taking into account the diversity of Indonesian culture. 3). Revitalize and strengthen the potential and competence of the education ecosystem.

Some of the main types of strengthening movement for character education values are religiosity, nationalism, independence, mutual cooperation, integrity, which are as follows:

\section{Religiosity}

Religiosity is often identified with diversity. Religiosity is defined as how far is knowledge, how solid is the belief, how much the implementation of worship and rules and how deep the appreciation of the religion it adheres to. For a Muslim, religiosity can be known from how far the knowledge, belief, practice and appreciation of the religion of Islam. In Islam, religiosity is largely reflected in the practice of faith, sharia, and morals, or with other expressions: faith, Islam, and ihsan. If all the elements have been owned by someone, then he is a true religious person.

Religiosity as religious meaning means covering various kinds or dimensions which not only occur when someone performs ritual behavior (worship), but also when carrying out other activities that are driven by supernatural powers. The attitude of religiosity in a society has a considerable influence on the clean behavior of the community (Yanuarti, 2018: 38). Several factors affect religiosity, namely: a. The influence of education or teaching and various social pressures (social factors), b. Various experiences experienced by individuals in shaping religious attitudes.

\section{Nationalism}

Nationalism is an understanding of the people of a nation that has cultural harmony, and the region as well as the similarity of ideals and goals so as to arise a sense of wanting to defend the country, both internal and external. Nationalism as an understanding of the "nation state" that grows over time with the end of a period of colonialism and imperialism of Western nations in the Third World (Masroer, 2017: 230). Nationalism has attitudes and behaviors that must be instilled in every society. The following are attitudes and behaviors in Nationalism, namely: Complying with the rules that pass, obeying State law, preserving Indonesian culture, creating and loving domestic products, willing to take concrete actions to defend, defend, and advance the State.

In a country there are several forms of nationalism that have existed for a long time. The following are forms of nationalism, namely: Nationalism of Citizenship, Ethnic Nationalism, Romantic Nationalism, Form of Cultural Nationalism, State Nationalism, Religious Nationalism. 


\section{Independence}

Independence is one aspect that is persisted by every teenager. Independence refers to an independent, creative and independent individual, that is, having self-confidence that can make a personable as an individual to adapt and take care of things with himself. A student's independence consists of several aspects of self-confidence, being able to work with oneself, respecting the time available, having a high desire to compete for progress, being very responsible and having the ability to make decisions (Said, Syafrina, and Tursinawati, 2017: 80). Independence refers to the belief in the ability of self to solve problems without special assistance from others, an unwillingness to be controlled by others, being able to carry out activities by themselves and solving the problems themselves.

\section{Mutual Cooperation}

Mutual cooperation is an activity carried out together and is voluntary so that the activities carried out can run smoothly, easily and lightly. Mutual cooperation is also very in accordance with the teachings of Islam, Islam wants its people to love, love and share with each other, it is very in line with the principle of mutual cooperation. The mutual cooperation attitude should be shared by all elements or layers of society both in cities and in rural areas. Because, with the awareness of every element or layer of society doing every activity by mutual cooperation. Some of the benefits of mutual cooperation are as follows:

So that our environment can be felt clean and beautiful, a sense of solidarity can be established in the community environment, so that community life is better with the holding of mutual cooperation, peace and peace, will be obtained if between fellow citizens care for each other and help each other fellow citizens. Mutual cooperation has grown and developed in our society for a long time. In the culture of mutual cooperation is inherent to the values of social capital substance. As social capital, mutual cooperation can be used as a reference and guide in achieving the progress of a nation.

\section{Integrity}

The meaning of integrity is the quality of honesty and moral principles in a person that is carried out consistently in his life as a whole. Integrity Gostick \& Dana Telford (2006, in Gea 2016) states that in the most recent Merriam-Wbster Dictionary defines integrity as a strong adherence to a code, specifically moral values or certain artistic values. Integrity can also be interpreted as a person's personality who acts consistently and intact, both in words and deeds, in accordance with values and code of ethics. A person is considered to have integrity when he has the following personalities and characters: Honest and trustworthy, Committed, Responsible, Keeping his words and Faithful.

Quality, character, or condition that shows a complete unity. so it has the 
potential and ability to radiate authority, honesty. Integrity seems to be insufficient to be represented by honesty, rigor in behavior, determination in commitment, or even virtue, virtue, and other values contained such as: simplicity, patience, visionary, courage, discipline, hard work, cooperation, responsibility, and so on (Endro, 2017: 150).

\section{b. Batik}

\section{History of Batik}

History of when batik first existed and was found in Indonesia, no one knows for sure, because the story in each country and region is different, in Java batik was initially only known in the palace environment, because in the past only palace people could wear batik in traditional ceremonies (Hermawati, Isma, $\&$ Mas, 2017). In the past the palace was the center of religion, government, customs and culture. But along with the development of the people around the palace began to recognize batik and began to make batik, for people in the palace, batik work is not just physical activity but is a meditation exercise so that the resulting fabric is usually magical. Whereas for people outside the palace, making batik is only used as a part-time job interrupted by their main work such as raising livestock, farming or fishing.

The types of batik produced were originally written batik which used natural dyes and were made limited for the purpose of traditional ceremonies, batik began to develop as a commercial commodity in the late 18th century and expanded until the 20th century. Batik production techniques continued to develop, initially batik using sticky rice porridge as a color barrier that is famous for the name "cymbals". Tools for making batik like a pencil from bamboo. After that was found the barrier material from the wasp night, which gradually developed into batik wax by using a variety of ingredients such as cat eye resin, animal fat, paraffin, gondorukem, micro-wax, sharp wax, wax wax and coconut oil with a certain dose. Canthing wrote, estimated to have been created in the Mataram palace environment in the 17 th century. In 1815, a copper stamp was made to make paintings on fabric by stamping a night-stamped stamp on the fabric. In 1902 a stamp was made of wood, but this tool could not develop in Javanese batik, but in Sumatra and Bukit Tinggi this stamp was still used.

In 1966 several batik artists began to emerge who introduced the technique of batik painting or batik painting. Tools for painting the brush or spoon, batik made with this painting technique developed in 1967 which is now known as Modern Batik, Freestyle Batik, Batik Painting or non-traditional batik. The following year, 1970, a writing canting that was heated using electricity or often called an "electric canting", but this tool has not yet developed its use. According to Utomo, Joebagio, and Djono (2018) said that para the written batik is still comfortable using manual canting because it is considered more safe and comfortable. 
According to the process batik is divided into three types namely written batik, printed batik and batik combination between written and stamped. Furthermore, in accordance with technological developments and saves production time, batik printing appears so that it can produce in large quantities and quickly. Even so this product cannot be classified as batik because it does not go through a process of enrichment or color barrier, so this product is only referred to as batik cloth not batik.

Batik craft in around 1800, using natural dyes derived from plants and animals with a coloring process that relatively requires a long time, the dyeing process takes 15-30 times, with each dyeing time of 15 minutes, then the colors used range blue, red and brown. Because of the limited colors produced by natural dyes and their processes which are considered time-consuming, batik entrepreneurs are starting to turn to synthetic dyes that have more diverse colors and shorten the time in the process. Especially the batik industry players who receive many orders of course the presence of synthetic dyes is very helpful for them in completing all orders on time.

Batik motifs are picture frames that embody batik as a whole. Batik motifs are also called batik patterns or batik patterns (Eskak, 2016: 13). The batik motif was made in the fields of triangle, rectangle, and / or circle. Batik motifs include animal, human, geometric, and other motifs. Batik motifs are often also used to show someone's status. Making batik is a hereditary tradition. Because of this, batik motifs are often the hallmark of batik produced by certain families.

Some batik may indicate the status of a person. Even today, some traditional batik motifs are only used by Yogyakarta and Surakarta palace families. Originally batik made on white material made of cotton called cloth Mori. Nowadays batik is also made on other materials such as silk, polyester, rayon and other synthetic materials. Batik motifs are formed with liquid wax by using a device called a canting for fine motifs, or a brush for large motifs, so that the waxy liquid seeps into the fabric fibers.

The variety of motifs and colors of batik is also influenced by various foreign influences. Initially, batik has a limited variety of motifs and colors, and some motifs may only be used by certain circles. But coastal batik absorbed various outside influences, such as foreign traders and also in the end, the invaders. Bright colors like red were popularized by the Chinese, who also popularized phoenix motifs. European invaders also had an interest in batik, resulting in previously unknown floral motifs such as tulips and also objects carried by the invaders (buildings or horse-drawn carriages), including their favorite colors such as blue. Traditional batik still retains its motives, and is still used in traditional ceremonies, because usually each motif has its own symbolism.

The following is the naming of batik based on the region of origin; Balinese Batik, Banyumas Batik, Besurek Batik, 
Madura Batik, Malang Batik, Pekalongan Batik, Solo Batik, Yogyakarta Batik, Tasik Batik, Aceh Batik, Cirebon Batik, Jombang Batik, Banten Batik, Tulungagung Batik, Kediri Batik, Kudus Batik, Jepara Batik.

There are thousands of batik motifs that have been created by artisans and artists in Indonesia. Thousands of batik motifs can be grouped into several Indonesian batik groups, namely: 1) Parang batik motifs. 2) Geometric batik motifs. 3) Banji batik motif. 4) Motifs of aquatic batik.

\section{History of Malangan Batik}

The history of batik is not yet known with certainty. but actually since the days of the Singosari Kingdom and the Kingdom of Kanjempuan, in those days the Malang area has had the characteristics of batik. Batik Malang more precisely begins since before the 1900 s, the benchmark is during the traditional ceremony of the XIX century. In the interior of Malang, the men and women use typical Malangan batik. The batik always has a Sidomukti Malang motif with a white box decoration in the middle, commonly called Modhang Koro. This motif is used as udheng (men's headband) and sewek (women's long cloth) in official events for all walks of life.

Malang Batik is usually called Malangan Batik, Malang Batik is not as famous as other batik in East Java, but the beauty of Malang Batik is not inferior to other regions, both from its own unique and unique batik style, or from its coloring. In the days of Malang batik kingdoms, they included motifs such as Sawat Kembang Pring (sakbarong Javanese bamboo motif), Dele Kecer (Soybean scattered) green-red, lily lotus flower (lily lotus flower), coffee flower (split coffee beans) black, Juwet flower (juwet flower) blue-green color, flower cape (cape flower, rounded jagged edge).

Batik Malangan is not so familiar to the people, to maintain this cultural heritage. In addition to maintaining the distinctive batik motifs Malangan heritage, the Malang government together with other relevant organizations are working on excavating new Malangan batik motifs.

\section{Malangan Batik Motif}

Excavation of batik motifs to be the hallmark of Malangan can be obtained from the temples from the kingdom of Kanjuruhan from the seventh century. One of the motifs that characterizes Malangan is the lotus flower motif. Batik Malangan has three main characteristics and is part of the three main components of batik: 1) First the basic motifs are in the form of clown temple motifs. Where the Badut temple is a relic of the Kanjuruhan kingdom in 760 AD 2) Both motifs of Isen-Isen, this motif consists of the image of the Malang Monument as the main motif beside which there is a white lion hair which is a symbol of Malang Regency. 3) Third is this batik ornamental motif itself,

Malang Batik, among others, has the Sawat Kembang Pring motif (sakbarong 
Javanese bamboo motif) Dele Kecer (green-red) Lotus Singo Kembang Kopi (picture of coffee halved in black) Kembang Juwet (blue-green) Kembang Tanjung (yellow-brown with ripe flower shape round center jagged edges) Kembang Jeruk (brown) Kembang Manggar (white-yellow) Kembang Mayang (red-yellow) and Kembang Padma (lotus) and so on.

Batik that is the hallmark of Malangan can be obtained from temples which are relics of the Kingdom of Kanjuruhan from the seventh century past. One of the unique and distinctive motifs of Malang Batik is Malang Malang Kucecwara motif. has a profound philosophy that there is a symbol of the image of the Malang Tugu Mahkota Rumbai Lion Lotus Flower Arca and tendrils and isen isen rhombus shape. Poor batik is famous for its batik motifs that tend to be bright, for example, the green color then overwrites it with white, then the white material is overwritten with red. Average malangan batik is patterned like flowers and plants, although there are indeed some motifs that describe honesty, courage, and singosari, such as poor motifs that only play in color without any patterns that form an object.

\section{Philosophy of Malangan Batik}

Various forms of motifs in Malang batik certainly also have their own philosophies, including:

1. Malang Monument: This motif is a symbol of regional power which we can also represent as a form of might and rigidity
2. Rumbai Lion: This motif is representative of the culture of the people of Malang at that time, where they have a brave spirit and spirit.

3. Lotus Flower: This motif symbolizes a natural beauty filled with fertility. According to some Hindu stories in the era of the kingdom of Singosari, this lotus flower is one type of flower of Lord Vishnu.

\section{Development of Malang Batik}

In its development, Malang batik has not been so well-known among the people in Indonesia as a whole, but the government itself is always trying to extract the latest Malang batik motifs together with several other related organizations by holding a fashion show and cultural performances to upload the cultural treasures of Malang and popularize the typical batik in Malang.

\section{METHODS}

\section{a. Research Approaches and Types}

The research approach used is a qualitative research approach with the type of descriptive research. The aim is to uncover the facts about the analysis of the character education of the machete batik mask as a form of character formation for elementary school children.

\section{b. Data source}

In every study, data is absolutely necessary. The research activity in this case is the collection and processing of data in accordance with the formulation and objectives of the study, therefore a 
data source is needed. Sources of data presented in this study are character education in typical Malangan batik, namely Parang Mask Batik. In this case, it discusses what the values of character education are contained in the Parang Mask batik.

\section{c. Data collection technique}

Data collection techniques are an important method in the research step and must be taken seriously to be used to collect data needed in research. Data collection techniques used in this study were observation techniques, interview techniques and study documentation.

\section{Observation Techniques}

The observations made in this study are direct observations namely data collection where researchers hold data observations directly on the subjects studied at the Soendari Gallery namely batik machete mask and then visualize and know character education.

2. Interview Technique

The aim of the researchers was to use interview techniques to explore data about the machete mask batik. The interview was conducted by the researcher directly to the owner of the Soendari Gallery to find out the machete batik motif then visualizing and knowing character education.

3. Documentation Techniques The documentation technique used by the author in this study is in the form of photographs of machete batik in Soendari Gallery and then visualizing and knowing character education.

\section{d. Research Instruments}

The research instrument used by the researchers themselves used tools, to retrieve the research data by using new structured interviews and using observation and documentation study in the form of photos from batik parang masks to capture instrument data related to the analysis of educational characters contained in batik parang masks. as a form of character orders for elementary school children.

\section{e. Data analysis technique}

The data analysis activities carried out by researchers in this study include:

1. Collecting data from observations, interviews, and documentation in the form of notes, recordings, photos and the resulting batik machete mask.

2. Grouping the data obtained into similar data related to the mask machete batik.

3. Analyzing the relationship between one data and other data related to the parang mask batik.

4. Re-check in the field if there is data that is incomplete, poorly understood, difficult to interpret or feels doubtful, so that the data from the research results will be more guaranteed to be true.

5. Compiling, discussing and describing the findings from the research results so that they 
become scientific papers that are worth reading.

6. Summing up the results of the research that has been done.

This template is aimed at helping authors to prepare their manuscript for the Journal of Teaching and Learning in Elementary Education. To use this template, the authors just delete the unwanted text and begin to type. The manuscript is written in good English. The authors can write either in British English or American English, but not both.

\section{RESULTS}

Analysing the character education of Parang mask batik as a form of character formation in elementary school children uses several instruments, namely the observation technique. The technique used in this study is direct observation, namely by conducting direct observation of data in the Soendari Gallery by elementary school students against batik parang masks (Figure 1), and then visualize and find out the character education contained in the banner mask. We also use the interview technique.

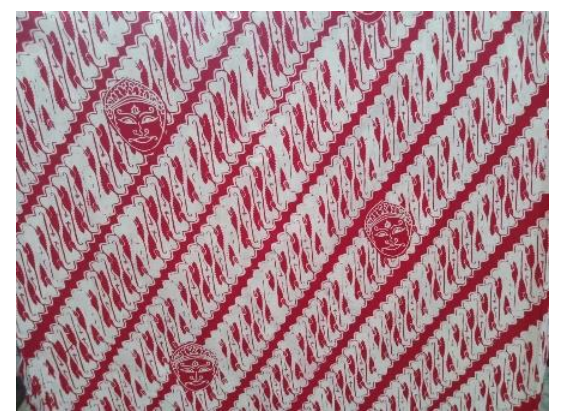

Figure 1. Pictures of Parang Mask Batik
This interview technique aims to dig up data about the machete batik mask. Interviews were conducted by researchers directly to the owner of the Soendari Gallery to find out the batik parang mask motif, then visualize and find out the character education contained in the banner mask. The next step, the technique used is the documentation technique. In this technique, the writer takes photos of mask machete batik at the Soendari Gallery, then visualizes and knows character education. In topeg panji parang batik, various decorative motifs are found with character values in them. In addition to the panji asmarabangun mask, there is a parang motif. In the parang mask batik there is also a line that appears obliquely from left to right. The color used in Batik Parang Mask is predominantly red.

In the parang mask batik, culture and education are reflected, and both have a reciprocal relationship because culture can be inherited through education, on the other hand, the form of education is also determined by the culture of the community. There is an interrelation between education and culture in the sense that one growth must be balanced with other growth, which is expected to have the potential to support each other in order to increase human dignity.Cultural values derived from the motif of the machete batik are basically sourced from ethos and aesthetics and aspects of life view of Javanese priyayi. Priyayi stressed the need for respect for the regularity of the hierarchy as a first 
step in the human journey to God. This hierarchical order is valuable to itself and therefore people must maintain it and put themselves in their place. Thus the community will be created as a unity in harmony with the demands of social etiquette. For this reason, in the context of Javanese society, three feelings must be developed, namely, wedi, isin and shyness.

The principle of harmony aims to maintain society in a harmonious state. The principle of respect is based on relationships in a hierarchically organized society. This hierarchical order is valuable to itself and therefore one must maintain it and put yourself according to it. Thereby maintaining the whole community, as a unified harmony is a requirement of social etiquette. Humans who successfully manage their behavior according to social manners will achieve equanimity. The transformation of priayi cultural values in the machete batik motifs is also based on order (hierarchy and harmonization) and guidance, shown in the following chart.

Parang mask batik motif is not only a physical reality but a form of collective thought that shows the complexity of ideas hidden in symbolism. Internalization of character values based on the culture of batik machete mask can be realized in learning in schools, especially those related to: a) Ideology; discipline, law and order, love the motherland, democracy, brave, loyal friend / solidarity, nationalism, patriotic, productive citizens, dignity / self-esteem, loyal / defending the country, b)
Religion; faith in God Almighty, obey God's commands love of religion, obey religious teachings, have good deeds, do good deeds, love to help and benefit others, pray and trust, care for others, humane, fair, moral, and wise, c) Culture; tolerance and good faith, kindness, empathy, procedure and etiquette, good manners, happy / happy, healthy, generous, friendship, recognition, respect, thanking.

\section{DISCUSSION}

Batik machete mask there is a form of Asmarabangun Panji Mask. In addition to the asmarabangun banner mask there is a form of a machete motif. Inside the machete batik mask there is also a line that appears sloping from left to right. The color used in Batik Parang Mask is dominated by red.

In the machete batik the mask is reflected in culture and education, and both have a reciprocal relationship because sustainable culture can be passed on through education, otherwise the form of implementing education is also determined by the culture of society (Tirtarahardja and Sulo, 2005). There is an interrelation between Education and culture in the sense that growth must be balanced with the growth of the other, which is expected to have the potential to support each other in order to improve human dignity.

Cultural values derived from the motif of the machete batik are basically sourced from ethos and aesthetics and aspects of life view of Javanese priyayi. Priyayi stressed the need for respect for 
the regularity of the hierarchy as a first step in the human journey to God. This hierarchical order is valuable to itself and therefore people must maintain it and put themselves in their place. Thus the community will be created as a unity in harmony with the demands of social etiquette. For this reason, in the context of Javanese society, it was developed three feelings that must be learned namely, wedi, isin, and shy. Meanwhile, to achieve harmony in community life is determined by two basic principles, namely harmony and respect (Suseno, 1991).

The principle of harmony aims to maintain society in a harmonious state. The principle of respect is based on relationships in a hierarchically organized society. This hierarchical order is valuable to itself and therefore people must maintain it and put themselves in accordance with it. Thereby maintaining the whole community, as a unified harmony is a requirement of social etiquette. Humans who successfully manage their behavior according to social manners will achieve equanimity. The transformation of priayi cultural values in the machete batik motifs is also based on order (hierarchy and harmonization) and guidance, shown in the following chart.

Parang mask batik motif is not only a physical reality but a form of collective thought that shows the complexity of ideas hidden in symbolism. Internalization of character values based on the culture of batik machete mask can be realized in learning in schools, especially those related to: a) Ideology; discipline, law and order, love the motherland, democracy, brave, loyal friend / solidarity, nationalism, patriotic, productive citizens, dignity / self-esteem, loyal / defending the country, b) Religion; faith in God Almighty, obey God's commands love of religion, obey religious teachings, have good deeds, do good deeds, love to help and benefit others, pray and trust, care for others, humane, fair, moral, and wise, c) Culture; tolerance and good faith, kindness, empathy, procedure and etiquette, good manners, happy / happy, healthy, generous, friendship, recognition, respect, thanking.

\section{CONCLUSION}

Local wisdom has an important role in changing global products to be meaningful and in accordance with local socio-cultural life. Education based on local wisdom proactively is able to face the challenges of globalization. Local wisdom as a tradition found shows that the culture of the past was not really enhanced even though the times have changed.

The character education contained in Parang Mask batik reflects the character values that can shape the character of elementary school children. Parang mask batik motif is not only a physical reality but a form of collective thought that shows the complexity of ideas hidden in symbolism. Internalization of character values based on the culture of batik machete mask can be realized in learning in schools, especially those related to: a) 
Ideology; discipline, law and order, love the motherland, democracy, brave, loyal friend / solidarity, nationalism, patriotic, productive citizens, dignity / self-esteem, loyal/ defending the country, b) Religion; faith in God Yang Almighty, obedient to God's commands love of religion, obedient to religious teachings, moral, do good, like helping and beneficial to others, praying and trusting, caring for others, humane, fair, moral and wise, c) Culture; tolerance and good faith, kindness, empathy, procedure and etiquette, good manners, happy / happy, healthy, generous, friendship, recognition, respect, thanking.

In the context of Indonesian character education is the process of harmonizing the human value system and the values of Indonesian culture in the dynamics of community, nation and state life. Nation character education is a process of civilizing and transforming human values and national cultural values to give birth to people or citizens of high civilization, citizens of character.

Characterization is the process of internalizing values that have reached the highest or deepest level. The appreciation of a value if it has reached a very deep level, then that value has characterized or become a characteristic marker of the person's personality.

\section{REFERENCES}

Effendy, M. (2016). Arahan Menteri Pendidikan dan Kebudayaan Muhadjir Effendy dalam Pelatihan Pengembangan Kapasitas untuk
Penguatan Pendidikan Karakter. Jakarta: Hotel Santika.

Endro, G. (2017). Menyelisik Makna Integritas dan Pertentangannya dengan Korupsi. Jurnal Integritas, 3(1), 131-152

Eskak, E. (2016). Pengembangan Motif Batik Khas Aceh Gayo. Jurnal Riset Industri. 10(1), 12-21.

Gostick, A., \& Telford, D. (2006). Keunggulan Integritas. Alih bahasa: Fahmi Ihsan. Jakarta: PT Bhuana Ilmu Populer.

Hapsari, W. (2015). Transformasi Hough Linear untuk Analisis dan Pengenalan Batik Motif Parang. Jurnal Informatika, 11 (2), 99-105.

Hermawati, A., El Isma, Y., \& Mas, N. (2017). Strategi Bersaing: Batik Malangan Konvensional Melalui Diversifikasi Produk Batik Kombinasi Pada Ukm Kelurahan Merjosari Malang. Jurnal Ilmiah Bisnis Dan Ekonomi Asia, 11(1), 11-23.

Koniyo, M. H., Lamusu, S. A., Hadjaratie, L., \& Bouty, A. A. (2015). Perancangan Aplikasi Rekomendasi Motif Karawo Berdasarkan Karakter Pengguna Berbasis Budaya Gorontalo. Prosiding Semnastek, 1-8. Masroer, (2017). Gagasan Nasionalisme Indonesia Sebagai Negara Bangsa Dan Relevansi Dengan Konstitusi Indonesia. Sosiologi Agama. Jurnal Ilmiah Sosiologi Agama dan Perubahan Sosial, 11(2), 229-237.

Nihayah, D. (2017). Implementasi Pendidikan Karakter di SDN 1 Cerme Kidul-Derme-Gresik. Jurnal JPGSD, $5(3), 1652-1662$. 
Said, S., \& Tursinawati, T. (2017). Analisis Kemandirian Siswa dalam Proses Pembelajaran di Kelas III SD Negeri 1 Banda Aceh. Jurnal Pesona Dasar, 1(5), 70-81.

Suseno, F. M. (1996). Etika Jawa, Sebuah Analisa falsafi tentang Kebijaksanaan Hidup Jawa, Jakarta: PT Gramedia Pustaka Utama.

Utomo, A. A. P., Joebagio, H., \& Djono, D. (2018). The Batik Latoh as the
Result of Maritime Culture of Lasem Community. International Journal of Multicultural and Multireligious Understanding, 5(3), 19-27. Yanuarti, E. (2018). Pengaruh Sikap Religiusitas Terhadap Perilaku Hidup Bersih dan Sehat Masyarakat Kabupaten Rejang Lebong. Jurnal Fokus Kajian Keislaman dan Kemasyarakatan, 3 (1), 21-40. 